\title{
CONSENSUS ANALYSIS, STATE PRACTICE, AND MAJORITARIAN ACTIVISM IN THE WTO
}

\author{
William J. Moon* and Alec Stone Sweett
}

World Trade Organization (WTO) judges regularly assess aggregate state practice and international standards when they adjudicate claims under Article XX of the General Agreement on Tariffs and Trade (GATT) ${ }^{1}$ and Art. XIV of the General Agreement on Trade in Services (GATS) ${ }^{2}{ }^{3}$ How they do so has helped to determine the institutional evolution of the WTO, given the paralysis of its legislative organs. In this comment, we consider the reports in the EC-Seal Products ${ }^{4}$ dispute in light of this view, as well as theory and evidence of a comparative nature.

\section{Necessity, Consensus, Majoritarian Activism}

For international courts that exercise compulsory jurisdiction over disputes involving state noncompliance with treaty law, the adjudication of derogation clauses are among the most significant and politically sensitive class of cases they confront. These clauses permit a state to maintain measures that would otherwise be unlawful under the treaty, insofar as such measures are "necessary" to achieve certain important public policy objectives. Although the states that founded the European Convention on Human Rights (ECHR), the European Union (EU), and the GAT'T-W'TO relied heavily upon such derogation clauses, to obtain agreement in the first place, they gave virtually no interpretive guidance on how "necessity" was to be determined. In effect, states delegated to judges the authority "to complete" expost what they had contracted as "incomplete" norms, ex ante. Similarly, they were silent as to the standard of review judges ought to adopt when considering the necessity defense, leaving yet another fundamental issue to be worked out through practice and judicial process. ${ }^{5}$

* Litigation Associate at Boies, Schiller \& Flexner, LLP.

† Leitner Professor of Law, Politics, and International Studies at the Yale Law School.

Originally published online 25 June 2015.

${ }^{1}$ General Agreement on Tariffs and Trade 1994, Apr. 15, 1994, Marrakesh Agreement Establishing the World Trade Organization, Annex 1A, 1867 UNTS 187.

${ }^{2}$ General Agreement on Trade in Services, Apr. 15, 1994, Marrakesh Agreement Establishing the World Trade Organization, Annex 1B, 1869 UNTS 183.

${ }^{3}$ We focus our analysis here on Article XX GATT, though some of the issues raised are directly relevant to the Agreement on the Application of Sanitary and Phytosanitary Measures, Apr. 15, 1994, Marrakesh Agreement Establishing the World Trade Organization, Annex 1A, 1867 UNTS 493 and the Agreement on Technical Barriers to Trade, Apr. 15, 1994, Marrakesh Agreement Establishing the World Trade Organization, Annex 1A, 1868 UNTS 120. See Gregory Shaffer, A Structural Theory of WTO Dispute Settlement: Why Institutional Choice Lies at the Center of the GMO Case, 41 N.Y.U. J. INT'L L. \& POL. 1 (2008).

4 Appellate Body Report, European Communities-Measures Prohibiting the Importation and Marketing of Seal Products, W'T/DS400/AB/R, WT/DS401/AB/R (Adopted June 18, 2014) [hereinafter Appellate Body Report, EC—Seal Products].

${ }^{5}$ The WTO legal system is a product of extensive incomplete contracting through which states also delegate authority to judges. See generally Gregory Shaffer \& Joel Trachtman, Interpretation and Institutional Choice at the WTO, 52 VA. J. INT'L L. 103 (2011); Alec Stone Sweet \& Thomas L. Brunell, Trustee Courts and the Judicialization of International Regimes, 1 J.L. \& CourTS 61 (2013). 
Partly in synergy with one another, the courts of each these regimes embraced, and then adapted to their own particular needs, a relatively intrusive standard — embodied in proportionality tests— to adjudicate derogation claims. ${ }^{6}$ As our readers will know, the framework requires states to justify measures under review with specific types of reasons, and then subjects those reasons to relatively robust scrutiny. ${ }^{7}$ In particular, states must show that the measure is designed to pursue a policy objective that is recognized as "legitimate" by the treaty; that there is a rational relationship between means and ends, and is not arbitrary or discriminatory in other ways; and that there is no reasonably available, more treaty compliant alternative. Within necessity tests, judges also weigh and balance the various factors of importance to the disputing parties and, often enough to matter a great deal, to the regime as a whole. Our interest here is on an additional factor in the adjudication of derogation clauses, the importance of gauging state practice - that is, discerning the extent of state policy consensus.

There exists relatively systematic empirical research on this question, and on how state consensus is determined in the ECHR, the EU, and the WTO. This research demonstrates that judges have developed a range of techniques for assessing aggregate state practice, and for analyzing international standards that are relevant to the dispute. They do so in order to arrive at some measure of the extent of consonance in state positions on a relevant policy issue, which they then treat as an important fact bearing on the case at hand. Put bluntly, ${ }^{8}$ judges in the EU and the ECHR are likely to reject a state claim to derogation for a type of measure that most other states do not (or no longer) view as necessary to achieve the same purposes; that is, the measure falls outside the zone of state consensus, or does not meet European or international standards in other ways. These same judges tend to accept a claim for a measure that falls within a zone of consensus, or of an emerging consensus. In the WTO, judges also engage in consensus analysis in the context of adjudicating pleadings under Article XX GATT and Article XIV GATS, though they do so more timidly and less intensively than the other courts.

Consensus analysis enables courts in these settings to pursue a strategy of "majoritarian activism." In its strongest formulation, majoritarian activism refers to the disposition of judges to produce rulings that are congruent with outcomes that states — as legislators — might adopt under majoritarian, but not unanimity, decision rules. Considered functionally, techniques associated with majoritarian activism can help to mitigate the legitimacy problems associated with judicial lawmaking under conditions of structural judicial supremacy, which pertain in each of these regimes, and render efforts at overriding their rulings, and curbing the growth of their authority, improbable or ineffective.

Although the practice developed only gradually, today the two European courts regularly count states, and then treat the tally as a factor that weighs heavily in the balance. In the WTO, panels and the Appellate Body (AB) rarely count states. Nonetheless, they do seek to identify state consensus on relevant law and practice, which they too treat as an important fact bearing on determining necessity. In most cases, this evidence helps in determining the outcome.

We have identified a range of basic techniques of consensus analysis in the adjudication of Article XX GATT and Article XIV GATS. WTO judges may reference established industry standards and state practices that point to available measures that are less trade restrictive than the measure under review. If a "usual," "normal," or "commonly used" technique or practice would entail measures that are more GATT consistent, then the defendant state loses. ${ }^{9}$ Similarly, judges may also refer to relevant measures of specific third-party states to help

${ }^{6}$ Alec Stone Sweet \& Jud Mathews, Proportionality Balancing and Global Constitutionalism, 47 COLUM. J. TranSNAT’L L. 72, 81 (2008).

${ }^{7} \underline{I d}$. at $79-80$ and, as applied to the GATT-WTO, $\underline{i d}$. at 153-60.

${ }^{8}$ For details and citations to the relevant literature, see Stone Sweet \& Brunell, supra note 5, at 85.

9 Among many, see Appellate Body Report, United States-Standards for Reformulated and Conventional Gasoline, WT/DS2/AB/R (Adopted May 20, 1996); Panel Report, European Communities-Protection of Trademarks and Geographical Indications for Agricultural Products and Foodstuffs, WT/DS290/R (Adopted Apr. 20, 2005); Appellate Body Report, China-Measures Affecting Imports of Automobile Parts, WT/DS339/AB/R, WT/DS340/AB/R, WT/DS342/AB/R (Adopted Jan. 12, 2009). 
them determine if a particular measure is in fact "necessary" to achieve a particular purpose, ${ }^{10}$ and states may also bring a count of states to the judges' attention. ${ }^{11}$ Relevant provisions of multilateral treaties and the positions taken by international organizations also serve as indicators of wider state consensus, as well as sources of law binding the defendant state. ${ }^{12}$ More generally, Korea-Beef ${ }^{3}$, the ruling that laid down guidelines for testing necessity — and which has been ritually cited in almost every subsequent case-indicates inter alia that the more state measures are designed to pursue "common interests or values" rather than narrow national interests, the more likely the $\mathrm{AB}$ will accept them as necessary to achieve state objectives under Article XX.

With this background in mind, we now turn to the dispute at hand.

\section{The Reports in EC-Seal Products}

The EU ban on the import and export of seal products grew out of several decades of social movement advocacy for the advancement of animal welfare. The principle of animal welfare in Europe is now enshrined in the Treaty of Lisbon ${ }^{14}$, which combines the instruments that today form the constitutional basis of the EU. ${ }^{15}$ While early legislative efforts concerning the protection of animals can be traced to $1974,{ }^{16}$ the ban on importation and sale of seal products was codified in Regulation No. 1007/200917 in 2009. The EU Seal Regime provided for a number of exceptions, including for seal products derived from hunts conducted by Inuit or indigenous communities (the IC exception) and hunts conducted for the purposes of marine resource management (the MRM exception). ${ }^{18}$

Canada and Norway challenged the EU Seal Regime as inconsistent with the GATT and TBT Agreements. Our focus here is on the relevant provisions under the GATT Agreement. In its ruling, the Panel concluded that the IC exception violated GATT Article I (the most-favored-nation clause) in that it granted an advantage to seal products originating in Greenland (specifically, its Inuit population) while at the same time according imported seal products from Canada and Norway less favorable treatment. Similarly, the Panel found that the MRM exception was inconsistent with GATT Article III (the national treatment clause) because it negatively

${ }^{10}$ Consider Appellate Body Report, Canada_Certain Measures Concerning Periodicals, WT/DS31/AB/R (Adopted July 30, 1997); Appellate Body Report, Thailand-Customs and Fiscal Measures on Cigarettes from the Philippines, WT/DS371/AR/R (Adopted July 15 2011).

11 E.g., Appellate Body Report, European Communities-Measures Affecting Asbestos and Products Containing Asbestos, WT/DS135/AB/R (Adopted Apr. 5, 2001).

12 Among many, Appellate Body Report, United States-Import Prohibition of Certain Shrimp and Shrimp Products, WT/DS58/AB/R (Adopted Nov. 6, 1998); Appellate Body Report, Mexico-Tax Measures on Soft Drinks and Other Beverages, WT/DS308/AB/R (Adopted Mar. 24, 2006); Appellate Body Report, China-Measures Related to the Exportation of Various Raw Materials, WT/DS394/AB/R, WT/DS395/AB/R, WT/DS398/AB/R (Adopted 22 Feb., 2012).

13 Appellate Body Report, Korea-Measures Affecting Imports of Fresh, Chilled and Frozen Beef, WT/DS161/AB/R, WT/DS169/AB/R (Adopted Jan. 10, 2001).

${ }^{14}$ Consolidated Versions of the Treaty on European Union and the Treaty of the European Union, 2010 O.J. (C83) 1.

15 In the Panel proceedings, the EC emphasized that moral concern with regard to the protection of animals is expressly enshrined in its constitutional treaties. Panel Report, European Communities-Measures Prohibiting the Importation and Marketing of Seal Products, para. 7.625, WT/DS400/R, WT/DS401/R (Adopted June 18, 2014) [hereinafter Panel Report, EC—Seal Products], (citing European Union's first written submission, para. 585).

${ }^{16}$ Robert Howse \& Joanna Langille, Permitting Pluralism: The Seal Products Dispute and Why the WTO Should Accept Trade Restrictions Justified by Noninstrumental Moral Values, 37 YALE J. INT'L L. 367, 374 (2012).

${ }^{17}$ Regulation (EC) No 1007/2009 of the European Parliament and of the Council of 16 September 2009 on trade in seal products (Text with EEA relevance), 2009 O.J. (L 286) 36.

${ }^{18}$ Commission Regulation (EU) No 737/2010 of 10 August 2010 laying down detailed rules for the implementation of Regulation (EC) No 1007/2009 of the European Parliament and of the Council on trade in seal products (Text with EEA relevance), 2010 O.J. (L 216) 1. 
affected the competitive opportunities for imported products. Having found violations under GATT Articles I and III, the Panel turned to the question of whether the EU's measure could be justified under Article XX(a), ${ }^{19}$ which permits a derogation for measures "necessary to protect public morals." Under now a well-established WTO jurisprudence, this involves a two-tiered analysis. A measure must, first, be provisionally justified under one of Article XX's headings, in this case, "public morals." If it does, then the measure must satisfy the requirements of the so-called "Chapeau": it may neither be applied in an arbitrary or discriminatory manner, nor constitute a "disguised restriction on international trade"20.21 Notably, the Panel found that the EU measure fell within the Article XX(a) exception for public morals in light EU public moral concerns for seal welfare. The Panel, however, concluded that the particular application of the measure did not comply with the additional non-discrimination requirements under the Article XX chapeau, suggesting how the EU can comply with its ruling in practice. ${ }^{22}$

The Panel opinion illustrates the potential role that consensus analysis can play in Article XX adjudication. On the question of whether the EU Seal Regime addressed legitimate moral concerns, the Panel relied on the recommendations of the World Organization for Animal Health (OIE); examined comparable limitations on the trade and marketing of seal products place in other states, ${ }^{23}$ and even commented, if only in footnotes, ${ }^{24}$ on the state of rapidly evolving debates on the morality of seal hunts in Canada and Norway. In summing up its approach, the Panel declared that "[i]nternational doctrines and measures of a similar nature in other WTO Members, while not necessarily relevant to identifying the European Union's chosen objective, illustrate that animal welfare is a matter of ethical responsibility for human beings in general" $25 .{ }^{26}$ Similarly, in judging the IC exception, the Panel relied on several proxies of international consensus, including the UN Declaration on the Rights of Indigenous Peoples, the ILO Convention concerning Indigenous and Tribal Peoples in Independent Countries, as well as similar measures adopted by other WTO Members on trade in products derived from marine mammals. ${ }^{27}$ As the Panel explained, "these sources, taken in their entirety as factual evidence, demonstrate the recognized interest of Inuit and indigenous people in preserving their traditions and cultures." 28

On appeal, Canada claimed that the Panel erred in "relying on international instruments extraneous to the case" 29 and, notably, that "the existence of international agreements that recognize, in general terms, the interest of indigenous people cannot be a determining factor in assessing whether the rationale for the regulatory distinction is justified." 30 While the AB chose not to address this latter argument directly, it upheld the Panel's

${ }^{19}$ General Agreement on Tariffs and Trade 1994.

20 Appellate Body Report, United States_Import Prohibition of Certain Shrimp and Shrimp Products, supra note 12, para. 120.

${ }^{21}$ For a commentary on the development of Article XX jurisprudence, see Stone Sweet \& Mathews, supra note 6, at 153-60, and Dukgeun Ahn, Note, Environmental Disputes in the GATT/WTO: Before and After US-Shrimp Case, 20 MiCH. J. INT'L L. 819 (1999).

22 See Gregory Shaffer \& David Pabian, European Communities-Measures Probibiting the Importation and Marketing of Seal Products, 109 AJIL 154 (2015).

23 Panel Report, EC-Seal Products, supra note 15, at paras. 7.408-09.

${ }^{24} \underline{I d}$. at nn.674 \& 676.

${ }^{25} \underline{I d}$. at para. 7.409 .

26 The footnote to this passage states: "We also take note of the United States' comment that 'while the focus must be on the responding Member's system and scale of values, what Members other than the responding Member consider to be public morals can offer confirmation of a panel's determination as to what constitutes a public moral within the system of the responding Member."' $\underline{I d}$. at n. 674 .

$27 \underline{I d}$ at paras. $7.292-95$

${ }^{28} \underline{I d}$. at para. 7.295 .

${ }^{29}$ Appellate Body Report, EC—Seal Products, supra note 4, at para. 2.4.

${ }^{30} \underline{I d}$. 
finding, after specifically noting the Panel's reliance on various international instruments. ${ }^{31}$ The $\mathrm{AB}$ also stressed, as it had in U.S.-Gambling32, that "Members should be given some scope to define and apply for themselves the concept of public morals according to their own systems and scales of values." 33

\section{An Assessment}

The AB opinion has been criticized by Greg Shaffer and David Pabian as lacking clarity and public reason, ${ }^{34}$ concerns that we share. In its report on EC-Seal Products, the AB dramatically declined an opportunity to consider, in broader terms, the legal, political, and cultural significance of the derogation offered under the "public morals" heading of Article XX. Instead, the AB adopts a timid posture, leaving it to future cases to clarify the nature and scope of public morals, even in its narrow legalistic guise. ${ }^{35}$ Within the confines of WTO jurisprudence, the $\mathrm{AB}$ leaves intact the basics of consensus analysis, as it has developed. Panels give some meaningful margin of appreciation with regard to a member's chosen ends, the extent of which will partly be determined by consensus analysis, while overseeing the measure's design and application under the Chapeau (see U.S.—Shrimp ${ }^{36}$ ). Under this brand of consensus analysis, state practice does not function to generate categorical rules or obligations, but rather enables WTO judges to consider multilateral consequences and solutions to what are, formally, conflicts among a small number of parties.

Viewed comparatively, the AB's ruling in EC — Seal Products does little to align WTO versions of consensus analysis with those of its peers in the ECHR and the EU. As the European regimes developed "constitutional" features, consensus analysis was gradually, and ever more explicitly, harnessed to a strategy of majoritarian activism, in the service of constructing a transnational—but meaningfully "constitutional" - collective identity. ${ }^{37}$ The $\mathrm{AB}$, of course, has asserted no such mandate, and would meet with massive resistance if it tried to do so. In the end, the Panel in EC-Seal Products found international instruments to be probative butperhaps disingenuously — only with regard to the EU's asserted values, not those of the WTO as a whole. ${ }^{38}$ We will be watching closely to see if WTO judges hold to this line in future cases.

${ }^{31} \underline{I d}$. at para. 5.138

32 Appellate Body Report, United States-Measures Affecting the Cross-Border Supply of Gambling and Betting Services, W'T/DS285/AB/R (Adopted Apr. 20, 2005).

33 Appellate Body Report, EC—Seal Products, supra note 4, at para. 5.199.

34 See Shaffer \& Pabian, supra note 22.

35 The need for general guidelines is all the more pressing given that clauses like Article XX(a) are largely devoid of legislative history (travaux préparatoires). See Steve Charnovitz, The Moral Exception in Trade Policy, 38 VA. J. INT’L L. 689, 704 (1998) (“There is very little legislative history for article XX(a).”); see also William J. Moon, Essential Security Interests in International Investment Agreements, $15 \mathrm{~J}$. INT'L ECON. L. 481, 481-82 (2012) (discussing the absence of preparatory work in the international investment treaty context).

36 Appellate Body Report, United States-Import Prohibition of Certain Shrimp and Shrimp Products, supra note 4.

37 Alec Stone Sweet, A Cosmopolitan Legal Order: Constitutional Pluralism and Rights Adjudication in Europe, 1 J. GLOBAL CONSTITUTIONALISM 53 (2012).

38 "In taking into account the recognition given by international instruments in the context of the United Nations and the ILO to the interests of Inuit and indigenous communities, the Panel is mindful that these instruments are not WTO instruments and they do not set out WTO obligations per se. We are considering the content of these instruments as part of the evidence submitted by the European Union to support its position concerning the interests of Inuit and indigenous communities, not as legal obligations of Members." Panel Report, EC—Seal Products, supra note 15, at n. 475. 